\title{
Land inequality and deforestation in the Brazilian Amazon
}

\author{
ANDRÉ ALBUQUERQUE SANT'ANNA \\ Brazilian Development Bank (BNDES) and Universidade Federal do Rio de \\ Janeiro (UFRJ), Av. Chile 330, 13th floor, Rio de Janeiro, RJ 20031-170, \\ Brazil.Email:andre.santanna@bndes.gov.br
}

Submitted 18 July 2014; revised 10 June 2015, 15 October 2015, 11 March 2016, 30 May 2016; accepted 18 July 2016; first published online 26 September 2016

\begin{abstract}
This paper investigates the relationship between land concentration and deforestation in the Brazilian Amazon. It develops a conceptual framework in which an individual may have three alternatives: to be a farmer in an already established place, to be a rural worker, or to migrate to the agricultural frontier in order to deforest. This model implies that land inequality affects deforestation positively. Based on data from municipalities with positive deforestation from 2002 to 2011, a model has been estimated to test this theoretical prediction. By making use of an instrumental variable, results show that there is statistical evidence to support the existence of a direct relationship between land inequality and deforestation. Results are stronger for the period 2002-2005. This might be due to command and control policies which have significantly increased the cost of clearing land since the mid-2000s.
\end{abstract}

\section{Introduction}

In recent decades there has been an increasing focus on the process of deforestation in the Amazon. This process has been viewed as a threat to the ecosystem with the greatest biodiversity in the world. In addition, the role of the Amazon as an important carbon sink has led to increasing concern over the impacts of land-use change on climate change. The Amazon forest has a crucial role in maintaining a regular climate not only locally but

The author would like to thank participants at the 20th Annual Conference of the European Environmental and Resource Economists, at the 40th Brazilian Meeting of Economics, and at the 2nd International Conference on 'Environment and Natural Resources Management in Developing and Transition Economies'. In addition, the author is grateful to Filipe Lage, Sébastien Marchand, Rudi Rocha, David Shepherd, Tania Shepherd, Leonardo Weller, an associate editor and two anonymous referees for comments and suggestions. He would also like to thank Camilla Aguiar for excellent research assistance, as well as Romero Rocha and Dimitri Szerman for kindly providing data on rural credit, rainfall and temperature. Any remaining mistakes, however, are the author's own. The opinions expressed in this paper are his and do not represent the institutions' view. 
across the whole of South America. The impacts of extreme events associated with climate change on both terrestrial and aquatic systems will be accentuated without the protection of native vegetation (Nobre, 2014).

Deforestation in the Amazon is deeply rooted in the process of land property accumulation. Due to its abundant natural resources, especially forests, the expansion of agricultural production has steadily relied on the extensive expansion of the frontier by clearing new plots of land. As a consequence, Brazil has lost almost all of its Atlantic rainforest, and large parts of both the Cerrado region and the Amazon have been reduced. ${ }^{1}$

In addition to the extensive occupation of the agricultural frontier as a means of expanding cattle and crop production, the pattern of land occupation in Brazil has another remarkable and historical feature: a highly skewed distribution of land. In fact, the existence of an elite based on land ownership and intense exploration of agricultural commodities remains as a historical trace in Brazil today (Dean, 1971).

Despite the importance of deforestation and land inequality in the process of land occupation in Brazil, these two phenomena have rarely been put together in a single framework. The literature on this theme is very sparse and even more so when the focus is the Brazilian Amazon. This, therefore, is the main contribution of this paper, namely, to establish a link between land inequality and deforestation in the last agricultural frontier in Brazil - the Legal Amazon.

As a starting point, a conceptual framework has been developed, in which agents - given endowments, prices and costs related to deforestation - choose their occupation. The agent must decide whether to become a farmer in an area that is already well established, or to be a rural worker, or to migrate to the frontier in search of economic opportunities and land to clear (Tole, 2004). The set of parameters and initial endowments will drive decision making. This is so because an appropriate way to understand the individual decision to clear land must lie in a framework of occupational (or asset composition) choice (Young, 1997; Takasaki et al., 2000). Therefore, it is assumed that deforestation results from an economic reasoning that compares payoffs from farming and from clearing land at the frontier. As such, the amount of land available for farming may be seen as a crucial element of the decision making.

Thus, the combination of low access to land, where the frontier is already well-established, and the economic opportunities associated with clearing land, creates a link between land inequality and deforestation. This is the main hypothesis that will guide the empirical analysis.

Based on this conceptual framework, this paper investigates whether land concentration played a crucial role in the deforestation of the Amazon between 2002 and 2011. Analysis is based on a sample of municipalities with positive deforestation in the Legal Amazon. Because throughout this period there was a substantial shift in deforestation, the sample is

${ }^{1}$ Dean (1997) offers a complete description of the process of occupation of the Brazilian territory and its consequences for the Atlantic rainforest. 
divided into two periods: 2002-2005 and 2006-2011. The dependent variable, annual deforested increment as a share of municipality area, is based on satellite images processed by the Brazilian National Institute for Space Research. The independent variable of interest is a constructed Gini index of land holdings. Based on migration patterns, a migration-weighted land Gini has been constructed. Each original municipality of migrants contributes to the composed land concentration index of the municipalities in the Legal Amazon. In addition, this variable is lagged in order to assess reverse causality issues.

Thus, this measure of land concentration is both exogenous to deforestation and makes more sense within the conceptual framework: an individual chooses either to be a farmer in an already well-established place or to migrate to the agricultural frontier. In addition, in order to avoid any remaining omitted variable bias, an instrumental variable (IV) for the composed Gini index has been included: a similarly migrationweighted variable of the amount of productive land kept idle as a share of total municipality area. Additionally, this instrument is measured 10 years before the variable of land inequality utilized. The argument for using this variable lies in the fact that the mean size of farms that keep idle productive land is larger than farms that make agricultural use of most of their available productive land (Assunção, 2008). This leads to a high correlation between the amount of idle land and the Gini index for land holdings.

Results point to a positive relationship between land inequality and deforestation in the Legal Amazon. Results are stronger for the period 2002-2005 than for 2006-2011. In order to avoid a conclusion relying on no more than the choice of time spans, a robustness check has been conducted in which three different periods are considered: 2002-2004, 2005-2008 and 2009-2011. Again, results show a decreasing effect as time elapses. A possible conjecture is that this might be related to important policy changes that were taken by the central government in 2004 and $2008 .^{2}$

Another caveat might be linked to the validity of the IV. The major concern with the exclusion restriction is that the IV could be correlated with some push factors to migration that are contemporaneous to the pattern of land inequality and, therefore, may have a direct effect on deforestation. Thus, in order to check for the validity of the instrument, a number of variables in the municipalities of origin are considered that could plausibly be correlated with both the IV and deforestation. Results in this exercise still point to a positive relationship between land concentration and deforestation.

The empirical findings suggest that, when the effects of land distribution on occupational choices and how they relate to deforestation are taken into account, it is clear that there is a substantial role for welfare improvements that may well lead to a situation with less deforestation and improved land use.

The remainder of this paper is organized as follows. In section 2, a brief revision of the related literature on land inequality and deforestation

2 See Assunção et al. (2015) for more details on these policies. 
is provided. Section 3 develops a simple theoretical model that highlights how land inequality might affect both decisions to clear land and possible policy responses and impacts. Section 4 describes the data set and descriptive statistics. Section 5 includes the empirical strategy and discusses the main results. Section 6 consists of overall conclusions and positive implications.

\section{Related literature}

In Brazil deforestation is highly associated with economic incentives provided by the profitability of activities associated with land-use change (e.g., unsustainable logging, cattle ranching, cultivation). Moreover, as property rights are badly defined, the process of deforestation improves the chance of acquiring property rights over land; this, in turn, may often lead to land speculation processes that reinforce even further land clearing (Fearnside, 1992; Schneider, 1994; Ozório De Almeida and Campari, 1995; Young, 1997; Angelsen, 1999; Margulis, 2003, Reydon and Fernandes, 2014). Some authors assign a role for the concentrated pattern of land occupation, as it results in exclusion from access to land as a motivation for deforestation (Becker, 1991; Fearnside, 1992, 2001; Walker and Homma, 1996).

Another major feature of the agricultural sector in Brazil is its remarkably high level of land inequality. Nevertheless, few authors provide empirical analysis regarding the relationship between land inequality and deforestation. Some authors - namely Caldas et al. (2007), Simmons (2005) and Alston et al. (1999) - analyze related issues, including the role of land reform, violence and wealth in terms of deforestation. Pacheco (2009) analyzes the effects of agrarian reform on both land distribution and deforestation.

Tole (2004) explicitly analyzes the relationship between land distribution and deforestation, although in a cross-country perspective. In her framework, the degree of land accessibility is a function of rural population density and land inequality, where unequal systems do worse in accommodating population pressures than more egalitarian systems. Thus, in her view the pattern of land distribution shapes decisions regarding deforestation.

Assunção and Ghatak (2003) explain the documented inverse relationship between farm size and productivity with heterogeneity in farming skills. According to these researchers, the average farm size of skilled farmers is smaller than that of unskilled farmers. Additionally, Assunção (2008) shows that the mean size of farms that keep idle productive land is larger than that of farms that make agricultural use of most of their available productive land. This provides a useful insight into understanding why land inequality leads to less land accessibility in the absence of rental and credit markets. Within such a framework, an increase in land inequality jointly decreases agricultural production and tends to increase deforestation.

Young and Neves (2009), for instance, provide evidence, from an analysis of municipalities in the Southeast and the Southern Brazilian Atlantic Forest, that there is no consistent correlation between deforestation and development. Although the authors do not propose a causal relation, it 
can be argued that if deforestation decreases development, it is another form of resource curse, where overexploitation of natural resources does not lead to development. Frankel (2010) highlights how poor institutions arise in rent-seeking and extractive states. ${ }^{3}$ Thus, it may be argued that those municipalities that apply more successful governance schemes will demonstrate improved results for both deforestation and development.

According to Engerman and Sokoloff (2002), poor institutions may be an outcome of factor endowments. Briefly stated, according to the authors factor endowments are central to structural inequality (usually associated to land inequality), which is in turn a determinant of poorly managed institutions, low human capital investment and, therefore, underdevelopment. ${ }^{4}$ Naritomi et al. (2012) provide evidence that those Brazilian municipalities associated with colonial rent-seeking episodes (sugar cane and gold colonial cycles) display lower provision of public goods and lower income per capita. ${ }^{5}$

Although this paper focuses only on the relationship between land inequality and deforestation, it is arguable that land concentration affects development under different forms. However, this paper will concentrate exclusively on the link between land inequality and deforestation.

\section{A simple model of land distribution and deforestation}

The model presented here describes a situation in which individuals have an occupational choice, where individuals maximize their expected utility by choosing what their occupation will be: a worker, a farmer or a migrant who will move to the frontier and clear land. The main argument is that what matters for an economic analysis of deforestation is the relative riskadjusted payoff. This point has also been argued by Tole (2004).

The key characteristic of this model is to address the effect of land concentration on deforestation, by reducing access to land. As land access is reduced, economic opportunities associated with deforestation at the frontier increase. Thus, ceteris paribus, higher land concentration leads to migration and promotes higher deforestation rates.

\subsection{Setup}

Consider an economy with infinite periods, overlapping generations and in which individuals live for two periods. In each period, a population with mass normalized to one is born and has a given wealth distribution $G_{t}(W)$. Initial wealth is received as a bequest.

${ }^{3}$ Marchand (2016) demonstrates that institutions have a differential impact on deforestation according to their respective colonial legacies.

4 There is a vast literature that builds on the Engerman and Sokoloff hypothesis. See, for instance, Easterly (2007) for a revision of the literature and for empirical results that confirm the hypothesis mentioned above.

${ }^{5}$ An interesting point made by these authors is that, as the analysis is within Brazil - a country that shares a single colonizer, a single language and is highly centralized - they are able to identify different de facto institutional arrangements that are associated with different factor endowments. 
In period $t$, individuals decide what to do with their wealth. That is to say, they may buy a plot of land $L$ at a price $p$, they may clear land $D$ at the frontier at a cost $c$, with $c<p$, or they may decide to enter the labor market and receive a wage, $w$. In the following period, agents receive their revenues (wages and profits) and sell their land to the new generation that is born, in order to consume. Agents are risk neutral and preferences are given by their consumption and whatever is bequeathed to the next generation.

Assunção (2008) has demonstrated that, within this type of framework, expected utility may be a function of profits as well as the value of land sold. It is further assumed that there are no credit or land rental markets. ${ }^{6}$ This means that $c D<W$ and $p L<W$. An important assumption to be made, as argued by Tole (2004), is that accessible land is a function of land inequality. ${ }^{7}$

If an individual decides to become a farmer, profit will be revenues received from the sale of agricultural products, $q$, less the wage paid to employees, $w$. Therefore, it is assumed that there will be a production function with fixed technology in labor and land. In this case, there are no capital gains after land is sold. If the decision is to clear land, it is assumed that the individual does not need to employ labor and receives a profit, $b .^{8}$ As everyone is a price taker in land, there is a possibility of capital gains, $p-c .^{9}$ This point is crucial, since it is well known that deforestation follows a speculative motive that is linked with the 'creation of property rights' (Sant'Anna and Young, 2010). ${ }^{10}$

\subsection{Occupational choices}

Summing up, individuals can invest in a farm, engage in deforestation or become agricultural workers. Given the structure described above, expected final wealth will be:

$$
E\left(W_{t+1}\right)=\left\{\begin{array}{c}
W_{t}+w \\
(p+b) D \\
(p+q-w) L
\end{array}\right\} .
$$

${ }^{6}$ In Brazil, only 4.5 per cent of total agricultural area was leased. This figure is even smaller in the Legal Amazon: 2.2 per cent was leased, according to the Agricultural Census of 2006. Furthermore, credit markets for land purchases are not well developed (cited by Assunção, 2008).

7 Nonetheless, instead of assuming $L=L(i)$, it will be assumed later that there is a threshold, $L^{F}$, which depends on the degree of land inequality.

${ }^{8}$ As a general rule, early settlers clear land and establish extensive cattle production that is not reliant on large-scale labor.

${ }^{9}$ However, these are simplifying assumptions that may be said to represent realistically the main features of the process of land occupation in the Amazon. For more on this process and how the present assumptions fit in relatively, see Ozório De Almeida and Campari (1995), Castro (2005) and Reydon and Fernandes (2014).

${ }^{10}$ Reydon and Fernandes (2014: 19) assert that 'the most important mechanism to avoid deforestation is the elimination of land speculation'. 
The occupational choice results from the comparison of the expected final wealth paths in (1). At this point, it assumed that land distribution is not binding on the size of $L$. Hence, individuals will choose to become farmers if their final wealth from farming is higher than that from clearing land and being a worker:

$$
r_{L}>g_{D}+r_{D} \quad \text { and } \quad W>\frac{w}{r_{L}} \equiv W_{0}
$$

where $r_{L}$ is the return on farming: $(q-w) / p ; g_{D}$ is the capital gain from selling deforested area: $(p-c) / c$; and $r_{D}$ is the return on activity after the land is cleared: $b / c$. Thus, in order to become a farmer, it is necessary that the return from this activity be larger than that from clearing land, and initial wealth must be larger than $w / r_{L}$.

In order to clear land at the frontier, as compared to becoming a worker, initial wealth must be larger than:

$$
W>\frac{w}{g_{D}+r_{D}} \equiv W_{1} .
$$

Assuming that there is up to that point a constraint on the size of $L$, it follows that:

Lemma 1. If $r_{L}>g_{D}+r_{D}$, occupational choices will be restricted to becoming a farmer or a worker, depending on initial wealth. There is no room for deforestation.

Proof: If $r_{L}>g_{D}+r_{D}$, it is easy to see that $W_{0}<W_{1}$. Therefore, if an individual has enough wealth to clear land, (s)he also has wealth to be a farmer at the old frontier.

Thus, occupational choices are fully determined by initial wealth and by the relationship between returns from farming and from deforestation.

\subsection{Introducing land inequality}

Now, suppose accessibility to land is completely related to land inequality. ${ }^{11}$ This is represented by assuming that there is a limit on the size of land available to be used, $L^{F}(i)<L$. In addition, when an individual receives her/his initial wealth, if her/his option is to keep farming, a portion of his/her wealth will be allocated to an asset that does not provide any interest payment, $m$. That is to say, $W_{t}=p L^{F}+m$. Thus, occupational choices become:

$$
E\left(W_{t+1}\right)=\left\{\begin{array}{c}
W_{t}+w \\
(p+b) D \\
(p+q-w) L^{F}+m
\end{array}\right\}
$$

${ }^{11}$ In order to assume this, Assunção's (2008) dictum has been has been followed, which argues that unproductive farms are (weakly) larger than agricultural farms on average. If larger farms are kept idle, the land inequality is assumed to be positively related to accessibility to land. 
Comparing final expected wealth, the occupational choice in favor of clearing as compared to working and to farming land will occur if:

$$
W>\frac{w}{g_{D}+r_{D}} \equiv W_{1} ; \quad W>\frac{r_{L} p L^{F}}{r_{D}+g_{D}} \equiv W_{2} .
$$

It is clear from (5) that the extent of land inequality, as $L^{F}=L^{F}(i)$, is a major determinant of the occupational choice. Again, when comparing payoffs between being a farmer and a worker, the following condition exists:

$$
L^{F}>\frac{w}{q-w}
$$

Substituting (6) into farmer's expected final wealth given by (4) yields:

$$
W>\left(1+\frac{1}{r_{L}}\right) w+m \equiv W_{3} .
$$

Thus $W_{3}$ is the threshold that determines the minimum wealth level in order to be a farmer.

\subsubsection{Equilibrium}

An equilibrium in the market for cleared land must equalize the aggregate demand and the supply of deforested land. Condition (5) determines that every individual with wealth greater than $W_{2}$ demands $W / c$ units of cleared land. Therefore, the equilibrium condition can be arranged as

$$
\int_{W_{2}}^{\infty} W d g(W)=c D
$$

Thus, the amount of cleared land within a world with land inequality is given by:

$$
D=\frac{\int_{W_{2}}^{\infty} W d G(W)}{c} .
$$

The result above leads to the following proposition:

Proposition 1. Deforestation is positively related to land inequality (i), land prices $(p)$, cattle ranching profits (b); and negatively related to cost of deforestation (c), and agricultural prices and yields (q). As for wages, the effect is ambiguous.

Proof: See online appendix B, available at http://dx.doi.org/10.1017/ S1355770X1600022X.

From the definition of $W_{2}$, it is expected that land inequality, land prices and profitability at the frontier should exert a positive influence on deforestation. On the other hand, profitability of farming and the cost of deforestation should decrease incentives for clearing land. Regarding wages, there are mixed signals: since they reduce the incentive to farm, they should 
have a positive influence on deforestation, by reducing $W_{2}$. Nevertheless, wages also represent an opportunity cost and, as this increases $W_{1}$, incentives to clear land are also reduced. ${ }^{12}$ Thus its influence on deforestation cannot be defined a priori.

The equilibrium in the labor market is defined by the aggregate demand for labor that results from farming decisions and supply of labor:

$$
\int_{W_{3}}^{W_{2}} W d G(W)=w G\left(W_{3}\right)
$$

The equilibrium wage rate is determined by the endowments of the economy and the wealth distribution.

\subsection{Empirical implications}

In accordance with the previous section, as inequality reduces access to land, individuals become more prone to clear land at the frontier. Therefore, deforestation will be positively affected by land inequality. The effect of land concentration need not be in the same municipality. Instead, it may be possible that inequality in the access to land works as a push factor leading to migration from one municipality to another in the agricultural frontier. This possibility will be fully explored in the empirical approach.

\section{Data}

The empirical analysis is based on a cross-section of municipalities that belong to the Legal Amazon covering the 2002-2011 period. The sample includes only municipalities that had new deforested areas. All of the Legal Amazon states are represented in the sample: Acre, Amapá, Amazonas, Mato Grosso, Maranhão, Pará, Rondônia, Roraima and Tocantins.

The analysis is split into two periods: from 2002 to 2005 and from 2006 to 2011. This division is due to two reasons. First, deforestation has significantly decreased since 2005. Another shift in its trend occurred in $2008 .^{13}$ Thus, it may not make sense to analyze two distinct periods in a single cross-section regression setting. Secondly, data for land concentration are only available from the Agricultural Census, with editions published in 1996 and 2006 and with data relating to December of its respective previous years. Hence, it is not feasible to use panel data estimations based on annual data. Therefore, the option was to use cross-sections in two distinct periods in order to estimate the effects of land concentration on deforestation. The following subsections describe the main variables used in this paper.

12 In recent years, the deforestation rate has significantly decreased. This fact may be related to real minimum wage gains and, generally, improvements in the labor market conditions in recent years. As such, this is as an interesting hypothesis to be explored in later studies.

13 Assunção et al. (2015) relate these shifts in trend to policies adopted by the Brazilian government. 


\subsection{Deforestation}

The National Institute for Spatial Research produces publicly available data on deforestation by municipality in the Brazilian Legal Amazon, through the Project for Monitoring Deforestation in the Legal Amazon (PRODES). PRODES processes satellite images in order to establish the amount of forested and deforested area in a given municipality. Deforestation is the increment in deforested area in a municipality between August of year $t-1$ and July of year $t$. The analysis is based on this periodicity because July and August are the least cloudy months in the region, thus minimizing measurement error problems.

Deforestation is defined as:

$$
D_{i t}=\ln \left(\frac{D e f_{i t}}{\text { Area }_{i}}\right)
$$

where $D e f_{i t}$ is the total deforestation that occurred in period $t ; t$ is defined as the period 2002-2005 for the first set of regressions and 2006-2011 for the second group; and $\mathrm{Area}_{i}$ is the total area of the municipality. Therefore, $D_{i t}$ is the normalized deforested area, since there is a substantial variability in total area and deforestation in the Legal Amazon.

\subsection{Land concentration}

The Brazilian Institute of Geography and Statistics (IBGE) publishes a detailed Agricultural Census, on a decennial basis, which permits the computation of a Gini index for land holdings. As the censuses were published in 1996 and 2006, referring to land ownership on 31 December of the previous years, data are only available for these years. Therefore, the analysis rests on the assumption that land inequality affects deforestation with a time lag. Furthermore, land concentration is quite stable. Therefore, it can be assumed that inequality from 1995 affects the pattern of deforestation in the period 2002-2005 and that inequality in land holdings in 2005 affects the deforestation process in the period 2006-2011, especially when one considers a Gini index based on the pattern of migrants, as explained below.

Land concentration may act as a push factor, expelling workers without opportunities to access land in a given municipality. ${ }^{14}$ Thus, it is expected that land concentration in municipality $j$ affects deforestation in municipality $i$. In order to account for this spatial pattern, a variable has been used that considers these effects of land inequality in other localities. The measure of migration-weighted land concentration for municipality $i$ is based on the municipalities of origin of its migrants. In order to do so, this is computed from populational censuses, published by IBGE, showing the number of the adult population in municipality $i$ that come from

${ }^{14}$ I would like to thank one of the referees for highlighting this point. 
other municipalities. A person is defined as a migrant if (s)he lives in the municipality for less than five years. ${ }^{15}$

Thus, the measure of land concentration is an unweighted average of the Gini of the municipalities from which the migrants came:

$$
\text { Composed Gini } i_{i t-h}=\sum_{j=1}^{n} n^{-1} * \text { Gini }_{j t-h},
$$

where $i$ is the total number of municipalities that supplied migrants to municipality $i$, irrespective of the number of migrants, Gini $i_{j t}$ is the land Gini index of municipality $j$ at period $t-h$. Here, $t-h$ is 1995 for the first group of regressions and 2005 for the second group.

It is also possible to define an alternative way of weighting land inequality by considering the share of migrants that each municipality $j$ contributed to the population of municipality $i$. In that case, the second measure of composed Gini becomes:

$$
\text { Gini_Migrants }_{i t-h}=\sum_{j=1}^{n}\left(\frac{\text { Migrants }_{j i t-z}}{\text { Total Migrants }_{i t-z}}\right) * \text { Gini }_{j t-h} \text {, }
$$

where Migrants $j i t-z$ is the number of migrants that have gone from municipality $j$ to $i$ in the previous five years. Total Migrantsit-z is the total in-migrant population of municipality $i$ in the previous five years.

As the formula takes into consideration the number of migrants, this second measure of land inequality may lead to an endogeneity problem: migration patterns may be affected by other factors such as the availability of roads. As roads connecting two cities reduce the cost of transport, this factor is expected to raise migration opportunities. Therefore, in this case it is harder to disentangle the effects of land concentration on deforestation. Thus, this variable will only be used as a robustness check to results with the preferred variable: Composed Gini $i_{i t-h}$.

It is worth noting that Arima et al. (2011) and Richards et al. (2014) use a similar approach to estimate the indirect effect of the agricultural sector, especially soybean production, on land use in Amazonia.

\subsubsection{Rural credit}

The Brazilian Central Bank compiles information about every contract of rural credit. Using this rich database, Assunção et al. (2012) constructed a data set of rural credit by municipality in the Legal Amazon. Here, the total

15 As populational censuses were carried out in 2000 and 2010, and agricultural censuses in 1995 and 2005, it is assumed that land inequality affected migration during these five years. 
amount of real rural credit normalized by the municipality area is used:

$$
\text { Credit }_{i t}=\ln \left(\frac{\text { rural credit }_{i t}}{\text { area }_{i}}\right) \text {. }
$$

Data on rural credit is available from 2003 to 2011. Subsequently, the mean of loans between 2003 and 2005 is taken for the first group of regressions, as well as the mean of rural credit $t_{i t}$ between 2006 and 2011 for the second set of estimations.

\subsection{Cattle prices}

A well-established result in the Brazilian Amazon is related to the importance of the expansion of cattle ranching to explain the pattern of deforestation. As this process is driven by the profitability of the activity, a proxy for cattle prices has been computed in each municipality following Assunção et al. (2015). These authors argue that prices cannot be considered in the Legal Amazon because this could lead to endogeneity problems. Thus, they consider prices in the southern state of Paraná as exogenous indicators. The prices are deflated to 2010 Brazilian Reais.

In order to have prices for each municipality, Assunção et al. (2015) will be followed and a weighted real price calculated according to:

$$
C P_{i t}=C P_{-} P R_{t} * \frac{\text { cattle }_{\text {head }} \text { it-x }}{\text { area }_{i}}
$$

Thus, prices in Paraná are weighted for each municipality in the Legal Amazon according to its intensity in cattle ranching as measured by the ratio of the number of head of cattle and total municipality area, considering a lag to avoid endogeneity issues. ${ }^{16}$ The period $t-x$ is considered as equal to the average of heads of cattle in 2000-2001 and 2004-2005, according to the respective groups of estimations. Finally, the mean of the natural logarithms of $C P_{i t}$ is taken for (in) the periods 2002-2005 and 2006-2011.

\subsection{Settlements}

The Brazilian Institute for Applied Economic Research (IPEA) gathers data on different kinds of information important for applied economic research and publicizes it through a website, IPEADATA. Data are available there on rural settlements for agrarian reform, originally informed by the National Institute of Colonization and Agrarian Reform (INCRA). Based on this, a measure of settlements was constructed for land reform for the periods 2002-2005 and 2006-2011. Thus,

$$
\text { Settlements }_{i t}=\frac{\text { Area of settlements to land reform }}{i t} \text {. }
$$

16 Using the total area minus the area occupied by cities and water does not change the results. 


\subsection{Geographical controls}

The literature on deforestation usually discusses the role of geographical variables in explaining municipality variability (e.g., Arima et al., 2011; Assunção et al., 2015). In order to control for these factors, the logarithm of mean values to rainfall and temperature during the relevant periods (20022005 and 2006-2011) were considered, as well as time-fixed variables such as altitude and the municipality coordinates. ${ }^{17}$

\section{Empirical model}

Deforestation rates show a high variability across the Legal Amazon. Indeed, even when one considers the intensity of deforestation, normalizing by the area of each municipality, there is still substantial variation.

As a first examination by comparing the regions of occurrence of deforestation and composed Gini, ${ }^{18}$ as defined in the section above, it seems that there is a geographical coincidence. Nevertheless, although suggestive, this observation is not conclusive and needs an empirical analysis.

\subsection{Identification strategy}

In accordance with the predictions of the theoretical framework presented above, there must be a positive association between the magnitude of land inequality and the deforestation rate. Nevertheless, two problems may arise when simply testing this correspondence using an ordinary least squares (OLS) estimation. First, it is possible to have a problem of reverse causality in the model. As deforestation is a form of land-use change, when increasing the supply of land for cattle ranching or agricultural use, it would be no more than coincidence if the concentration of land holdings were not affected. Secondly, the relation proposed might possibly be driven by omitted variable bias.

In order to deal with these potential biases in the estimator, the measure of land concentration is lagged and based on other municipalities, according to the pattern of migration to the municipalities of interest. Thus, the identification strategy adopted relies on the assumption that the way land concentration has been accounted for is not related to the error term.

Therefore, benchmark specification is defined by:

$$
D_{i t}=\beta_{1} * \text { Composed Gini } i_{i t-h}+\beta_{2} X_{i t}+\text { State }_{i}+\varepsilon_{i t},
$$

where $D_{i t}$ and Composed $\mathrm{Gini}_{i t-h}$ are exactly as defined in the section above. $X_{i t}$ is a vector of control variables containing municipality-level information according to the discussion, and State $_{i}$ is a dummy for the state to which the municipality belongs. Finally $\varepsilon_{i t}$ is the error term.

In spite of the fact that the measure of land inequality can deal with reverse causality problems, there is still room for omitted variable bias. For

17 As for rain and temperature, annual estimates were used for each municipality according to the PRODES year (from August of $t-1$ to July of $t$ ).

18 Maps are provided in figures A.2-A.5 in the online appendix. 
example, agricultural and land prices may influence both the pattern of land concentration, even considering distinct localities, and the process of deforestation.

Then, in order to overcome this possible bias, an IV approach is proposed. This instrument is the ratio of idle productive land to total municipality area. As the Composed Gini variable, this ratio is composed according to the municipalities of origin of migrants to locality $i$. The argument for using this variable lies in Assunção's 2008 findings that unproductive farms are larger than agricultural farms on average. Thus, a positive relation between land concentration and the amount of idle productive land should be found.

Regarding concerns with validity of the instrument, the variable is measured 10 years before the land concentration measure is utilized. Thus, the instrument of Composed Gini in 1995 is Composed idle land in $1985 .{ }^{19}$ In addition, as argued by Walker and Homma (1996), in established frontiers, land scarcity arises in part due to land kept idle by large land owners, leading to a process of land concentration. ${ }^{20}$ The difficulties imposed for small producers leads them to bankruptcy and outmigration to new frontiers (Wood, 1983, cited in Walker and Homma, 1996).

\subsection{Results}

Table 1 presents results with OLS estimations for three different measures of land inequality: (i) Composed Gini; (ii) the alternative measure, Gini_Migrants; and (iii) the Gini index of land holdings of the municipality $i$, Gini.

From table 1, it is possible to observe, as a first analysis, that there is a positive relationship between land concentration and deforestation, especially for the period 2002-2005. The variable Gini_Migrants is that which has more economic and statistical significance in both periods. Nonetheless, this might be affected by the availability of a network of roads which facilitates migration from a given municipality $j$ to a municipality $i$ at the frontier, as discussed above. Therefore, it is believed that this variable is more suitable to endogeneity problems than the Composed Gini variable. Finally, the Gini of the municipality itself is significant, albeit small and with its sign moving from positive to negative across time periods. Overall, coefficient estimators have a significant drop from the period 2002-2005 to the period 2006-2011. A possible explanation for this pattern may lie in the more stringent policies related to deforestation adopted, from 2004 and, in a second stage, 2008.

Considering the caveats on the use of Gini_Migrants, table 2 presents OLS estimation for the period 2002-2005, using the variables Composed Gini and Gini and controlling for a handful of covariates related to policy, prices and geography. Table 3 presents the same estimations for the period 2006-2011.

Again, estimates for the Composed Gini show a positive, albeit declining, relationship between land concentration and deforestation when taking

19 The same applies for 2005, where the measure of idle land is from 1995.

20 See Walker and Homma (1996) for a complete description of this process. 
Table 1. Ordinary least squares estimation

\begin{tabular}{|c|c|c|c|c|c|c|}
\hline Variables & $\begin{array}{c}\text { (1) } \\
2002-2005\end{array}$ & $\begin{array}{c}(2) \\
2002-2005\end{array}$ & $\begin{array}{c}(3) \\
2002-2005\end{array}$ & $\begin{array}{c}(4) \\
2006-2011\end{array}$ & $\begin{array}{c}\text { (5) } \\
2006-2011\end{array}$ & $\begin{array}{c}(6) \\
2006-2011\end{array}$ \\
\hline Composed_Gini_95 & $\begin{array}{c}0.047^{* * * *} \\
(0.015)\end{array}$ & & & & & \\
\hline Gini_migrants_95 & & $\begin{array}{c}0.066^{* * *} \\
(0.009)\end{array}$ & & & & \\
\hline Gini_95 & & & $\begin{array}{c}0.011^{* *} \\
(0.005)\end{array}$ & & & \\
\hline Composed_Gini_05 & & & & $\begin{array}{c}0.016 \\
(0.020)\end{array}$ & & \\
\hline Gini_migrants_05 & & & & & $\begin{array}{c}0.014^{* * *} \\
(0.005)\end{array}$ & \\
\hline Gini_05 & & & & & & $\begin{array}{c}-0.012^{* *} \\
(0.005)\end{array}$ \\
\hline Constant & $\begin{array}{c}-7.831^{* * *} \\
(1.114)\end{array}$ & $\begin{array}{c}-5.070^{* * *} \\
(0.120)\end{array}$ & $\begin{array}{c}-5.118^{* * *} \\
(0.388)\end{array}$ & $\begin{array}{c}-6.183^{* * *} \\
(1.470)\end{array}$ & $\begin{array}{c}-5.278^{* * *} \\
(0.123)\end{array}$ & $\begin{array}{c}-4.114^{* * *} \\
(0.372)\end{array}$ \\
\hline Observations & 611 & 611 & 611 & 626 & 626 & 626 \\
\hline$R^{2}$ & 0.015 & 0.086 & 0.008 & 0.001 & 0.011 & 0.008 \\
\hline
\end{tabular}

Notes: Analysis is based on a cross-section of municipalities located in the Legal Amazon states of Acre, Amapá, Amazonas, Mato Grosso, Maranhão, Pará, Rondônia, Roraima and Tocantins, which exhibited variation in forest cover during the sample periods. The dependent variable is the log of the annual deforestation increment as a share of total municipality area. Robust standard errors are clustered at the municipality level. Significance: ${ }^{* * *} p<0.01,{ }^{* *} p<0.05$. 
Table 2. Ordinary least squares estimation, 2002-2005

\begin{tabular}{lcccc}
\hline Variables & $(1)$ & $(2)$ & $(3)$ & $(4)$ \\
Composed_Gini_95 & $0.027^{*}$ & $0.041^{*}$ & & \\
& $(0.015)$ & $(0.021)$ & & \\
Credit_area_05 & $0.114^{*}$ & $0.151^{* * *}$ & $0.108^{*}$ & $0.146^{* *}$ \\
& $(0.058)$ & $(0.058)$ & $(0.059)$ & $(0.058)$ \\
Cattle_prices_05 & $0.201^{* * *}$ & $0.240^{* * *}$ & $0.207^{* * *}$ & $0.241^{* * *}$ \\
& $(0.056)$ & $(0.066)$ & $(0.056)$ & $(0.066)$ \\
Settlements_05 & 0.014 & -0.012 & 0.013 & -0.013 \\
& $(0.013)$ & $(0.015)$ & $(0.012)$ & $(0.015)$ \\
Gini_95 & & & 0.001 & 0.002 \\
& & & $(0.005)$ & $(0.005)$ \\
Observations & 587 & 587 & 587 & 587 \\
$R^{2}$ & 0.101 & 0.308 & 0.097 & 0.303 \\
Geographic controls & NO & YES & NO & YES \\
State dummy & NO & YES & NO & YES \\
\hline
\end{tabular}

Notes: Analysis is based on a cross-section of municipalities located in the Legal Amazon states of Acre, Amapá, Amazonas, Mato Grosso, Maranhão, Pará, Rondônia, Roraima and Tocantins, which exhibited variation in forest cover during the sample periods. The dependent variable is the log of the annual deforestation increment as a share of total municipality area. Robust standard errors are clustered at the municipality level. Significance: ${ }^{* * *} p<0.01$, ** $p<0.05, p^{*}<0.1$.

into account covariates including cattle prices, credit, geographic localization and state dummies. ${ }^{21}$ During the period 2002-2005, the estimator is positive and statistically significant. In the period 2006-2011, significance disappears. Regarding the coefficients of Gini, they, again, are unstable and without significance.

As expected, cattle prices and rural credit have positive and relatively stable positive coefficients. These results are in line with a large number of authors' findings and signal that there are strong economic incentives for deforestation in the Brazilian Amazon region (Alston et al., 1999; Margulis, 2003; Roebeling and Hendrix, 2010; Hargrave and Kis-Katos, 2013; Assunção et al., 2015). In fact, as observed in section 2, deforestation confers on the occupant greater capitalization (because deforested land is more valued) and provides benefits through the sale of wood and the development of cattle activities. ${ }^{22}$

Another policy variable, rural settlements to land reform, fails to present statistical significant coefficients. This result suggests that settlements in the Amazon do not present additional pressure on deforestation. In fact,

21 Some geographical variables, such as altitude and coordinates, are time-invariant. This helps to deal with unobserved effects that could lead to omitted variable bias.

${ }^{22}$ For a description of this process, see Castro (2005). 
Table 3. Ordinary least squares estimation, 2006-2011

\begin{tabular}{lcccc}
\hline & $(1)$ & $(2)$ & $(3)$ & $(4)$ \\
Variables & OLS & OLS & OLS & $\begin{array}{c}\text { OLS } \\
\text { 2006-2011 }\end{array}$ \\
\hline Composed_Gini_05 & 0.018 & 0.005 & & \\
& $(0.021)$ & $(0.028)$ & & \\
Credit_11 & -0.053 & $0.123^{* *}$ & -0.027 & $0.121^{* *}$ \\
& $(0.061)$ & $(0.060)$ & $(0.057)$ & $(0.060)$ \\
Cattle_prices_11 & $0.275^{* * *}$ & $0.260^{* * *}$ & $0.257^{* * *}$ & $0.257^{* * *}$ \\
& $(0.053)$ & $(0.052)$ & $(0.052)$ & $(0.051)$ \\
Settlements_11 & -0.020 & -0.037 & -0.016 & -0.037 \\
& $(0.029)$ & $(0.027)$ & $(0.028)$ & $(0.027)$ \\
Gini_05 & & & $-0.012^{* *}$ & -0.002 \\
& & & $(0.005)$ & $(0.005)$ \\
Observations & 602 & 602 & 602 & 602 \\
$R^{2}$ & 0.091 & 0.333 & 0.098 & 0.334 \\
Geographic controls & NO & YES & NO & YES \\
State dummy & NO & YES & NO & YES \\
\hline
\end{tabular}

Notes: Analysis is based on a cross-section of municipalities located in the Legal Amazon states of Acre, Amapá, Amazonas, Mato Grosso, Maranhão, Pará, Rondônia, Roraima and Tocantins, which exhibited variation in forest cover during the sample periods. The dependent variable is the log of the annual deforestation increment as a share of total municipality area. Robust standard errors are clustered at the municipality level. Significance: ${ }^{* * *} p<0.01$, ** $p<0.05$.

Soave Junior et al. (2014) show that deforestation trends in the Legal Amazon and within settlements are very similar.

As argued before, the OLS estimator can still suffer from omitted variable bias. Therefore, table 4 presents the two-stage least squares (2SLS) estimation, using the instrument described above.

Results under 2SLS estimation show a positive and robust coefficient for land inequality. However, according to Baum and Schaffer (2007), in order to test for weak identification, one should apply the 'rule of thumb' that the $F$-statistic should be at least 10 in order for weak identification not to be considered a problem. Once this is applied, only the results for the period 2002-2005 appear to be robust.

\subsection{Robustness checks}

5.3.1. Exclusion restriction and additional controls

Although results in table 4 show that the IV is related to inequality, it is not clear that the exclusion restriction holds. That is to say, conditional on the controls included in table 4 , the amount of idle productive land (10 years before the period under analysis) in the municipalities from which migrants came should have no effect on deforestation in Amazonian municipalities, other than its effect through land inequality. The major concern with this exclusion restriction is that the IV could be correlated with certain push factors to migration that are contemporaneous to the 
Table 4. Two-stage least squares estimation

\begin{tabular}{lcc}
\hline Variables & $(1)$ & $(2)$ \\
\hline Panel A: 2SLS & $2002-2005$ & $2006-2011$ \\
Composed_Gini & $0.618^{* * *}$ & \\
& $(0.229)$ & $0.633^{* *}$ \\
Credit_area & $0.223^{* *}$ & $(0.269)$ \\
& $(0.087)$ & 0.179 \\
Cattle_prices & $0.216^{* *}$ & $(0.116)$ \\
& $(0.092)$ & $0.437^{* * *}$ \\
Settlements & 0.023 & $(0.108)$ \\
& $(0.029)$ & $-0.066^{*}$ \\
Panel B: first stage of Composed Gini & $0.186^{* * *}$ & $(0.035)$ \\
Composed_Idle_Land & $(0.057)$ & $0.220^{* * *}$ \\
& -0.167 & $(0.078)$ \\
Credit_area & $(0.104)$ & -0.099 \\
& 0.029 & $(0.119)$ \\
Cattle_prices & $(0.121)$ & $-0.300^{* * *}$ \\
Settlements & -0.051 & $(0.105)$ \\
& $(0.034)$ & $0.066^{*}$ \\
Observations & 587 & $(0.036)$ \\
$R^{2}$ & 0.611 & 602 \\
Geographic controls & YES & 0.460 \\
State dummy & YES & YES \\
Kleibergen-Paap rk Wald $F$-statistic & 10.758 & YES \\
\hline
\end{tabular}

Notes: Analysis is based on a cross-section of municipalities located in the Legal Amazon states of Acre, Amapá, Amazonas, Mato Grosso, Maranhão, Pará, Rondônia, Roraima and Tocantins, which exhibited variation in forest cover during the sample periods. The dependent variable is the log of the annual deforestation increment as a share of total municipality area. Robust standard errors are clustered at the municipality level. Significance: ${ }^{* * *} p<0.01$, ${ }^{* *} p<0.05,{ }^{*} p<0.1$.

pattern of land concentration and, therefore, may have a direct effect on deforestation.

Therefore, in order to check for the validity of the instrument, a number of variables have been taken into consideration in the municipalities of origin that could plausibly be correlated with both the IV and deforestation. The variables included are seen as possibly affecting the decision to migrate to the frontier. The share of employment in the primary sector, unemployment rate, educational attainment and demographic density are considered in the main regression. In addition, as described by Sousa (2013), some externalities are important when it comes to pushing migrants from their original locality: violence, measured as homicide rate, and sanitation coverage represent this kind of externality that might also affect the decision to migrate. These variables are constructed in the same way as the Composed_Gini variable, as described before: they are calculated as unweighted averages of the municipalities of origin of migrants. 
Table 5 presents the 2SLS estimation, using the additional controls described above. Overall, comparing results from tables 4 and 5, it can be seen that the results change remarkably little with the inclusion of additional controls. Thus, results from table 5, with additional controls, seem to reinforce the validity of the instrument, especially for the period 2002-2005.

Table 5. Robustness checks: two-stage least squares with additional controls

\begin{tabular}{|c|c|c|c|c|}
\hline Variables & $\begin{array}{c}(1) \\
2002-2005\end{array}$ & $\begin{array}{c}(2) \\
2002-2005\end{array}$ & $\begin{array}{c}(3) \\
2006-2011\end{array}$ & $\begin{array}{c}(4) \\
2006-2011\end{array}$ \\
\hline \multicolumn{5}{|l|}{ Panel A: 2SLS } \\
\hline Composed_gini & $\begin{array}{c}0.576^{* * *} \\
(0.210)\end{array}$ & $\begin{array}{c}0.536^{* * *} \\
(0.172)\end{array}$ & $\begin{array}{l}0.975^{* *} \\
(0.464)\end{array}$ & $\begin{array}{l}0.714^{*} \\
(0.410)\end{array}$ \\
\hline Comp_pop_density & $\begin{array}{l}-0.009 \\
(0.133)\end{array}$ & $\begin{array}{c}0.052 \\
(0.138)\end{array}$ & $\begin{array}{l}-0.264 \\
(0.247)\end{array}$ & $\begin{array}{l}-0.266 \\
(0.193)\end{array}$ \\
\hline $\begin{array}{l}\text { Comp_share_employed_ } \\
\text { primary_sector }\end{array}$ & $\begin{array}{l}0.050^{*} \\
(0.028)\end{array}$ & $\begin{array}{c}0.033 \\
(0.026)\end{array}$ & $\begin{array}{l}0.089^{*} \\
(0.051)\end{array}$ & $\begin{array}{l}0.100^{* *} \\
(0.045)\end{array}$ \\
\hline $\begin{array}{l}\text { Comp_Expected_Years_ } \\
\text { Educ }\end{array}$ & $\begin{array}{l}-0.107 \\
(0.245)\end{array}$ & $\begin{array}{c}0.066 \\
(0.203)\end{array}$ & $\begin{array}{l}2.197^{* *} \\
(0.901)\end{array}$ & $\begin{array}{l}1.620^{*} \\
(0.909)\end{array}$ \\
\hline $\begin{array}{l}\text { Comp_Unemployment_ } \\
\text { rate }\end{array}$ & $\begin{array}{l}-0.207^{* *} \\
(0.099)\end{array}$ & $\begin{array}{c}-0.244^{* * *} \\
(0.093)\end{array}$ & $\begin{array}{c}-0.771^{* * *} \\
(0.277)\end{array}$ & $\begin{array}{c}-0.800^{* * *} \\
(0.305)\end{array}$ \\
\hline Comp_Homicide_rate & & $\begin{array}{l}-0.048 \\
(0.049)\end{array}$ & & $\begin{array}{c}0.102 * * * \\
(0.036)\end{array}$ \\
\hline $\begin{array}{l}\text { Comp_sanitation_ } \\
\text { coverage }\end{array}$ & & $\begin{array}{l}-0.026 \\
(0.029)\end{array}$ & & $\begin{array}{c}0.001 \\
(0.049)\end{array}$ \\
\hline Controls & YES & YES & YES & YES \\
\hline Geographic controls & YES & YES & YES & YES \\
\hline State dummy & YES & YES & YES & YES \\
\hline \multicolumn{5}{|c|}{ Panel A: first stage for Composed Gini } \\
\hline composed_idle_land & $\begin{array}{c}0.196^{* * *} \\
(0.056)\end{array}$ & $\begin{array}{c}0.231^{* * *} \\
(0.056)\end{array}$ & $\begin{array}{l}0.165^{* *} \\
(0.075)\end{array}$ & $\begin{array}{l}0.146^{* *} \\
(0.073)\end{array}$ \\
\hline Comp_pop_density & $\begin{array}{c}0.079 \\
(0.200)\end{array}$ & $\begin{array}{l}-0.179 \\
(0.195)\end{array}$ & $\begin{array}{c}0.180 \\
(0.234)\end{array}$ & $\begin{array}{c}0.175 \\
(0.233)\end{array}$ \\
\hline $\begin{array}{l}\text { Comp_share_employed_ } \\
\text { primary_sector }\end{array}$ & $\begin{array}{l}-0.022 \\
(0.041)\end{array}$ & $\begin{array}{c}0.051 \\
(0.042)\end{array}$ & $\begin{array}{l}-0.029 \\
(0.047)\end{array}$ & $\begin{array}{c}0.010 \\
(0.055)\end{array}$ \\
\hline $\begin{array}{l}\text { Comp_Expected_Years_ } \\
\text { Educ }\end{array}$ & $\begin{array}{l}0.497^{*} \\
(0.282)\end{array}$ & $\begin{array}{l}-0.197 \\
(0.318)\end{array}$ & $\begin{array}{c}-1.636^{* * *} \\
(0.336)\end{array}$ & $\begin{array}{c}-1.896^{* * *} \\
(0.413)\end{array}$ \\
\hline $\begin{array}{l}\text { Comp_Unemployment_ } \\
\text { rate }\end{array}$ & $\begin{array}{l}-0.043 \\
(0.133)\end{array}$ & $\begin{array}{c}0.133 \\
(0.140)\end{array}$ & $\begin{array}{l}0.438^{* *} \\
(0.188)\end{array}$ & $\begin{array}{c}0.598^{* * *} \\
(0.214)\end{array}$ \\
\hline Comp_Homicide_rate & & $\begin{array}{c}0.198^{* * *} \\
(0.059)\end{array}$ & & $\begin{array}{l}-0.003 \\
(0.041)\end{array}$ \\
\hline $\begin{array}{l}\text { comp_sanitation_ } \\
\text { coverage }\end{array}$ & & $\begin{array}{c}0.129^{* * *} \\
(0.033)\end{array}$ & & $\begin{array}{c}0.065 \\
(0.043)\end{array}$ \\
\hline Controls & YES & YES & YES & YES \\
\hline Geographic controls & YES & YES & YES & YES \\
\hline State dummy & YES & YES & YES & YES \\
\hline Observations & 587 & 587 & 602 & 602 \\
\hline$R^{2}$ & 0.615 & 0.640 & 0.489 & 0.494 \\
\hline
\end{tabular}


Table 5. Continued.

(1)

(2)

(3)

(4)

\begin{tabular}{lcccc} 
Variables & $2002-2005$ & $2002-2005$ & $2006-2011$ & $2006-2011$ \\
\hline $\begin{array}{c}\text { Kleibergen-Paap rk } \\
\text { Wald F-statistic }\end{array}$ & 12.337 & 16.838 & 4.852 & 3.935 \\
\hline
\end{tabular}

Notes: Analysis is based on a cross-section of municipalities located in the Legal Amazon states of Acre, Amapá, Amazonas, Mato Grosso, Maranhão, Pará, Rondônia, Roraima and Tocantins, which exhibited variation in forest cover during the sample periods. The dependent variable is the log of the annual deforestation increment as a share of total municipality area. Composed variables consider the municipalities of origin of migrants, as described in the text for the Composed_Gini. Additional controls are cattle prices and rural credit, both measured at the municipalities of analysis. Robust standard errors are clustered at the municipality level. Significance: ${ }^{* * *} p<0.01,{ }^{* *} p<0.05$, $* p<0.1$

\subsubsection{Different time spans}

The results shown above might be driven by the time spans chosen for deforestation rates. In this section, an alternative period classification was chosen in order to test whether results are robust to these alternative specifications.

As Assunção et al. (2015) point out, there were two major shifts in command and control policies for deforestation in the Legal Amazon. First, in 2004, a new plan - the PPCDAm - was launched to combat deforestation. The second turning point was the passing of a presidential decree that selected a list of priority municipalities in which to combat deforestation in 2008.

Given these two shifts, in this section, the sample was split into three different periods: 2002-2004, when deforestation reached its maximum; 2005-2008, marked by a shift in the trend; and 2009-2011, with much smaller levels of deforestation, driven by a second shift in the deforestation trend.

Indeed, as can be seen from table 6 , results are valid only in the period 2002-2004. For the periods 2005-2008 and 2009-2011, the estimator for the effects of land inequality is not different from zero. ${ }^{23}$

\subsubsection{Panel structure}

Another way to deal with unobserved effects is to consider a panel structure based on the two periods considered: using a fixed effects model allows us to identify the effects of land concentration on deforestation independent of time-invariant omitted variables. In addition to fixed effects, table 7 presents results based on a panel with the IV above considered.

${ }^{23}$ Even when one considers alternative variables for land concentration, results lose economic and statistical significance. Results are not reported and may be requested from the author. 
Table 6. Robustness checks: different time spans

(1)

\begin{tabular}{lr} 
Variables & OLS 2002-2 \\
\hline Composed_Gini_95 & $0.050^{* *}$ \\
& $(0.023)$ \\
Credit_area_04 & $0.124^{* *}$ \\
Cattle_prices_04 & $(0.060)$ \\
& $0.239^{* * *}$ \\
& $(0.073)$
\end{tabular}

Composed_Gini_05

Credit_area_08

Cattle_prices_08

Credit_area_09

Cattle_prices_09

Observations

$R^{2}$

Geographic controls

State dummy
(2)

OLS 2005-2008
(3)

OLS 2009-2011

Notes: Analysis is based on a cross-section of municipalities located in the Legal Amazon states of Acre, Amapá, Amazonas, Mato Grosso, Maranhão, Pará, Rondônia, Roraima and Tocantins, which exhibited variation in forest cover during the sample periods. The dependent variable is the log of the annual deforestation increment as a share of total municipality area. Robust standard errors are clustered at the municipality level. Significance: ${ }^{* * *} p<0.01$, ** $p<0.05$.

Results still point to a positive relationship between land inequality and deforestation, although not statistically significant when considering a fixed effects with IV model. Although different from other results in this paper, it is perhaps unsurprising. Within the period of analysis, the Amazon experienced a large shift in command and control policies that led to a substantial increase in the cost of deforestation, thus leading to a discontinuity in deforestation figures. Therefore, as land inequality has an inertial structural pattern without any sharp changes, when one uses a panel approach, the relationship under investigation is masked by other important factors that are changing fast, such as conservation policies. In such a context, the policy discontinuity increases the cost of deforestation and is not fully captured by the controls, even when controlling for time fixed effects such as heterogeneity in the timing of the introduction of conservation policies is substantial across municipalities.

Thus, the fixed effects model, although helpful in dealing with timeinvariant unobservable variables, has a noisy within-variation since deforestation has decreased in the second period due to the shift in its cost, 
Table 7. Robustness checks: panel with two stage least squares

\begin{tabular}{|c|c|c|}
\hline Variables & (1) & (2) \\
\hline $\begin{array}{l}\text { Panel A: 2SLS } \\
\text { composed_gini }\end{array}$ & $\begin{array}{c}0.074 \\
(0.086)\end{array}$ & $\begin{array}{c}0.163 \\
(0.133)\end{array}$ \\
\hline Comp_pop_density & & $\begin{array}{c}0.011 \\
(0.060)\end{array}$ \\
\hline Comp_share_employed_primary_sector & & $\begin{array}{l}-0.026 \\
(0.025)\end{array}$ \\
\hline Comp_Expected_Years_Educ & & $\begin{array}{l}0.575^{* *} \\
(0.225)\end{array}$ \\
\hline Comp_Unemployment_rate & & $\begin{array}{l}-0.046 \\
(0.051)\end{array}$ \\
\hline Comp_Homicide_rate & & $\begin{array}{l}-0.007 \\
(0.016)\end{array}$ \\
\hline Comp_sanitation_coverage & & $\begin{array}{c}-0.076^{*} \\
(0.043)\end{array}$ \\
\hline Municipality fixed effects & YES & YES \\
\hline Time fixed effects & YES & YES \\
\hline Controls & YES & YES \\
\hline Geographic controls & YES & YES \\
\hline \multicolumn{3}{|l|}{ Panel A: first stage for Composed Gini } \\
\hline Composed_idle_land & $\begin{array}{c}0.291^{* * *} \\
(0.104)\end{array}$ & $\begin{array}{l}0.201^{* *} \\
(0.086)\end{array}$ \\
\hline Comp_pop_density & & $\begin{array}{l}-0.084 \\
(0.225)\end{array}$ \\
\hline Comp_share_employed_primary_sector & & $\begin{array}{c}0.151^{* * *} \\
(0.048)\end{array}$ \\
\hline Comp_Expected_Years_Educ & & $\begin{array}{c}-1.508^{* * *} \\
(0.407)\end{array}$ \\
\hline Comp_Unemployment_rate & & $\begin{array}{l}-0.015 \\
(0.170)\end{array}$ \\
\hline Comp_Homicide_rate & & $\begin{array}{c}0.082 \\
(0.054)\end{array}$ \\
\hline Comp_sanitation_coverage & & $\begin{array}{c}0.306^{* * * *} \\
(0.047)\end{array}$ \\
\hline Municipality fixed effects & YES & YES \\
\hline Time fixed effects & YES & YES \\
\hline Controls & YES & YES \\
\hline Geographic controls & YES & YES \\
\hline Observations & 1136 & 1136 \\
\hline Municipalities & 568 & 568 \\
\hline$R^{2}$ & 0.095 & 0.177 \\
\hline Kleibergen-Paap rk Wald $F$-statistic & 7.856 & 2.701 \\
\hline
\end{tabular}

Notes: Analysis is based on a panel of municipalities located in the Legal Amazon states of Acre, Amapá, Amazonas, Mato Grosso, Maranhão, Pará, Rondônia, Roraima and Tocantins, which exhibited variation in forest cover during the sample periods. The dependent variable is the $\log$ of the annual deforestation increment as a share of total municipality area. Composed variables consider the municipalities of origin of migrants, as described in the text for the Composed_Gini. Additional controls are cattle prices and rural credit, both measured at the municipalities of analysis. Robust standard errors are clustered at the municipality level. Significance: ${ }^{* * *} p<0.01,{ }^{* *} p<0.05,{ }^{*} p<0.1$. 
which is an unobservable variable that is varying in time. Overall, these results may be interpreted by the theoretical model provided in section 3 . As government policies have become stricter in relation to deforestation, they can be interpreted as an increase in the cost of deforestation. This increase in the cost, as argued by proposition 1 , leads to a reduction in the activity of clearing land. Thus, the effect of land inequality becomes ceteris paribus less important.

\section{Conclusion}

This work investigated the impacts of land inequality on deforestation. In order to gain some intuition, a simple model of occupational choice was developed. It concludes that land inequality, by reducing access to land, is positively related to deforestation. In the following, this proposition was tested empirically.

The main identification strategy was to use an IV in order to deal with potential endogeneity problems. Empirical results confirm the theoretical hypothesis and show a positive relationship between land concentration and deforestation. Results are stronger for the first period considered, 2002-2005. One conjecture for this is the increase in the cost of deforestation that occurred with the introduction of important command and control policies. This cost shift might have reduced the push factor for migration induced by the unequal pattern of land distribution in Brazil. Nevertheless, albeit less significantly, results for the period 2006-2011 still point to a positive relationship between land inequality and deforestation.

The results of the present paper may provide interesting references for governmental policies regarding the relationship between land distribution and deforestation. Therefore, there is a substantial role for welfare improvements which ought to lead to a situation with less deforestation and improved land use.

\section{Supplementary materials and methods}

To view supplementary material for this article, please visit http:/ / dx.doi. org/10.1017/S1355770X1600022X

\section{References}

Alston, L.J., G.D. Libecap, and B. Mueller (1999), 'A model of rural conflict: violence and land reform policy in Brazil', Environment and Development Economics 4(2): 135-160.

Angelsen, A. (1999), 'Agricultural expansion and deforestation: modelling the impact of population, market forces and property rights', Journal of Development Economics 58(1): 185-218.

Arima, E.Y., P. Richards, R. Walker, and M.M. Caldas (2011), 'Statistical confirmation of indirect land use change in the Brazilian Amazon', Environmental Research Letters 6(2): 1-7.

Assunção, J. (2008), 'Rural organization and land reform in Brazil: the role of nonagricultural benefits of landholding', Economic Development and Cultural Change 56(3): 851-870. 
Assunção, J. and M. Ghatak (2003), 'Can unobserved heterogeneity in farmer ability explain the inverse relationship between farm size and productivity?', Economics Letters 80(2): 189-194.

Assunção, J., C. Gandour, R. Rocha, and R. Rocha (2012), 'Deforestation slowdown and rural credit policies in the Brazilian Amazon', Paper presented at the 34th Brazilian Econometric Society, 11-14 December.

Assunção, J., C. Gandour, and R. Rocha (2015), 'Deforestation slowdown in the Brazilian Amazon: prices or policies?', Environment and Development Economics 20(6): 697-722.

Baum, C. and M.E. Schaffer (2007), 'Enhanced routines for instrumental variables/GMM estimation and testing', Boston College Economics Working Paper No. 667, Chestnut Hill, MA.

Becker, B. (1991), Amazônia (2nd edn), São Paulo: Editora Ática.

Caldas, M.M., R.T. Walker, E. Arima, S. Perz, S. Aldrich, C.S. Simmons, and C. Wood (2007), 'Theorizing land use and land cover change: the peasant economy of Amazonian deforestation', Annals of the Association of American Geographers 97(1): 86-110.

Castro, E. (2005), 'Dinâmica socieconômica e desmatamento na Amazônia', Novos Cadernos NAEA 8(2): 5-39 [in Portuguese].

Dean, W. (1971), 'Latifundia and land policy in nineteenth-century Brazil', Hispanic American History Review 51(4): 606-625.

Dean, W. (1997), With Broadax and Firebrand: the Destruction of the Brazilian Atlantic Forest, Berkeley, CA: University of California Press.

Easterly, W. (2007), 'Inequality does cause underdevelopment: insights from a new instrument', Journal of Development Economics 84(2): 755-776.

Engerman, S.L. and K.L. Sokoloff (2002), 'Factor endowments, institutions, and differential paths of growth among new world economies', Economia 3(1): 41-109.

Fearnside, P.M. (1992), 'Desmatamento e desenvolvimento agrícola na Amazônia Brasileira', in P. Léna and A.E. Oliveira (eds), Amazônia: A Fronteira Agrícola 20 Anos Depois (2nd edn), Belém: Museu Paraense Emílio Goeldi [in Portuguese].

Fearnside, P.M. (2001), 'Land-tenure issues as factors in environmental destruction in Brazilian Amazon: the case of southern Pará', World Development 29(8): 13611372.

Frankel, J. (2010), 'The natural resource curse: a survey', HKS Faculty Research Working Paper No. RWP10-005, Harvard Kennedy School, Cambridge, MA.

Hargrave, J. and K. Kis-Katos (2013), 'Economic causes of deforestation in the Brazilian Amazon: a panel data analysis for the 2000s', Environmental and Resource Economics 54(4): 471-494.

Marchand, S. (2016), 'The colonial origins of deforestation: an institutional analysis', Environment and Development Economics 21(3): 318-349.

Margulis, S. (2003), Causes of Deforestation of the Brazilian Amazon, Washington DC: World Bank.

Naritomi, J., R. Soares, and J. Assunção (2012), 'Institutional development and colonial heritage within Brazil', Journal of Economic History 72(2): 393-422.

Nobre, A.D. (2014), 'O futuro climático da Amazônia', Relatório de Avaliação Científica, Sao Paolo: Articulación Regional Amazônica [in Portuguese].

Ozório De Almeida, A.L. and J. Campari (1995), Sustainable Settlement in the Amazon, Washington, DC: World Bank.

Pacheco, P. (2009), 'Agrarian reform in the Brazilian Amazon: its implications for land distribution', World Development 37(8): 1337-1347.

Reydon, B.P. and V.B. Fernandes (2014), 'The necessity of land governance: sustainable development in the Amazon', Policy in Focus 29: 18-20. 
Richards, P.D., R.T. Walker, and E.Y. Arima (2014), 'Spatially complex land change: the indirect effect of Brazil's agricultural sector on land use in Amazonia', Global Environmental Change 29: 1-9.

Roebeling, P.C. and E.M.T. Hendrix (2010), 'Land speculation and interest rate subsidies as a cause of deforestation: the role of cattle ranching in Costa Rica', Land Use Policy 27: 489-496.

Sant'Anna, A.A. and C.E.F. Young (2010), 'Property rights, deforestation and rural conflicts in the Amazon', Economia Aplicada 14(3): 377-387.

Schneider, R. (1994), Government and the Economy of the Amazon Frontier, LAC Regional Studies Program Report No. 34, Washington, DC: World Bank.

Simmons, C.S. (2005), 'Territorializing land conflict: space, place, and contentious politics in the Brazilian Amazon', Geojournal 64: 307-317.

Soave Junior, M.A., O.S. Martins, P.R.S. Moutinho, and S.M. Rodrigues (2014), 'Sustainable settlements in the Amazon', Policy in Focus 29: 32-34.

Sousa, F.L. (2013), 'Does crime affect migration flows?', Papers in Regional Science 93(S1): 99-111.

Takasaki, Y., B. Barham, and O.T. Coomes (2000), 'Wealth accumulation and activity choice evolution among Amazonian forest peasant households', University of Wisconsin-Madison Staff Paper No. 434, Madison, WI.

Tole, L. (2004), 'A quantitative investigation of the population-land inequality land clearance nexus', Population and Environment 26(2): 75-106.

Walker, R. and A.K.O. Homma (1996), 'Land use and land cover dynamics in the Brazilian Amazon: an overview', Ecological Economics 18: 67-80.

Young, C.E.F. (1997), Economic adjustment policies and the environment: a case study for Brazil, Ph.D. dissertation, University College London, London.

Young, C.E.F. and A.C.M. Neves (2009), 'Destroying the myth: deforestation, rural employment and human development in the Brazilian Atlantic Forest', IV Congreso de la Asociación Latinoamericana y del Caribe de Economistas Ambientales y de Recursos Naturales, Heredia: Universidade Nacional de Costa Rica. 